Síntese - Rev. de Filosofia

V. 32 N. 104 (2005): 401-428

\title{
A DOUTRINA LOCKIANA DOS DIREITOS NATURAIS COMO FUNDAMENTAÇÃO DA DEFESA DOS DIREITOS HUMANOS
}

Otacílio Rodrigues da Silva

U E C E

Resumo: Este artigo busca apresentar as idéias fundamentais da doutrina dos direitos naturais segundo a concepção de John Locke como uma proposta de fundamentação da defesa dos Direitos Humanos. Aqui serão desenvolvidos os seguintes temas: a) jusnaturalismo tradicional; b) jusnaturalismo moderno; c) jusnaturalismo lockiano; d) direitos naturais (vida, liberdade e propriedade); e) defesa dos direitos humanos. 0 pensamento de Locke sobre os direitos naturais é vastíssimo e se encontra presente em suas diversas obras e diferentes perspectivas de análise. Contudo, daremos ênfase às perspectivas antropológica e ética. Antropologicamente, 0 indivíduo é entendido como um ser dotado de direitos, cuja tarefa das instituições é conservá-los. 0 caráter ético se manifesta a partir da socialização e universalização dos direitos em função da promoção humana.

Palavras-chave: Doutrina, Locke, Direitos Naturais, Direitos Humanos.

Abstract: This article aims at presenting the fundamental ideas of John Locke's natural rights doctrine as the basis for the defense of Human rights. The following themes will be analyzed here: a) traditional jusnaturalism; b) modern jusnaturalism; c) lockeian jusnaturalism; d) natural rights (life, freedom and property); e) defense of human rights. Locke's thought on natural rights is very wide and appears in several of his works with different perspectives. However, we will give emphasis to the anthropological and ethical analyses. Anthropologically speaking, human-beings are 
conceived as people having rights and the task of institutions is to preserve those rights. The ethical attribute reveals itself from the socialization and universalization of the rights towards human promotion.

Key-Words: Doctrine, Locke, Natural Rights, Human Rights.

\section{Introdução}

$\mathrm{N}$ este artigo, pretendo discutir como o filósofo empirista John Locke (1632 -1704), ao seu modo, compreendeu e apresentou a sua doutrina do direito natural, confrontando-a com 0 jusnaturalismo tradicional e o jusnaturalismo moderno. Busca-se fazer uma abordagem da doutrina lockiana dos direitos naturais como fundamentação da defesa dos direitos humanos.

Quanto à estrutura formal, o artigo é constituído de dois tópicos fundamentais: em primeiro lugar, faz-se uma abordagem histórica das diferentes doutrinas do direito natural a fim de confrontá-las com as características específicas da doutrina lockiana; em segundo lugar, apresentam-se propriamente os direitos naturais do homem especificados na doutrina de Locke e a defesa dos direitos humanos.

Trata-se de um esforço de apresentar as principais idéias lockianas sobre os direitos naturais, cujo caráter normativo possui uma validade imutável como fundamentação da defesa dos Direitos Humanos, a fim de que os poderes constituídos visem à conservação dos direitos naturais do homem a partir da ordem social e da autonomia dos cidadãos.

\section{I - Doutrina do direito natural}

O pensamento político de Locke faz parte da corrente filosófica jusnaturalista ${ }^{1}$. Todavia, as diversas interpretações da teoria política lockiana apresentam divergências quanto à sua pertença ao jusnaturalismo tradici-

\footnotetext{
${ }^{1}$ J usnaturalismo é a corrente filosófica ou doutrina que sustenta a existência de uma lei natural, no sentido de que as suas normas precedem logicamente às leis ou aos direitos positivos que emanam de uma autoridade política ou religiosa. A história do conceito do direito natural nos remete à filosofia clássica, e quando se fala de «doutrina» ou de «escola» do direito natural, com o termo «jusnaturalismo» faz-se referência ao desenvolvimento e à difusão que a antiga corrente do direito natural teve durante a I dade Moderna, no período que ocorre entre o início do século XVI e o final do século
} 
onal ou ao jusnaturalismo moderno ou a uma posição intermediária². Por isso, percebe-se a necessidade de clarificar a posição lockiana do direito natural, apresentando as características fundamentais das respectivas doutrinas e as mutações que essas sofreram na elaboração da doutrina lockiana do direito natural. Busca-se, então, analisar os principais expoentes das doutrinas do direito natural ao longo da história do pensamento filosófico a fim de situar a posição de Locke quanto à doutrina do direito natural.

\section{Doutrina tradicional do direito natural}

O jusnaturalismo estóico-aristotélico apresenta uma estrutura constituída de quatro elementos básicosi: a) a natureza possui uma ordem que tem uma estrutura normativa; b) a existência de uma doutrina jusnaturalista do conhecimento que possibilita deduzir normas válidas para o agir humano a partir da ordem natural do universo; c) a existência de uma teoria relativa à força vinculante da lei natural; d) a existência de uma relação entre a lei natural e a ordem política.

Aristóteles distingue o direito natural do direito positivo. 0 direito natural se refere às ações boas ou más em si mesmas; por isso tem uma validade universal ao estabelecer aquilo que é justo ou injusto. 0 direito positivo ou legal, ao contrário, refere-se às ações indiferentes, (ações que antes de serem estabelecidas pelas normas civis, conforme 0 direito natural, não são nem boas nem más em si mesmas). Ele possui uma validade particular e mutável ${ }^{4}$. Aristóteles diz também que se houver uma discordância entre 0 direito natural e 0 direito positivo, dar-se-á preferência ao direito natural ${ }^{5}$.

Segundo a concepção estóico-cristã, existe uma lei natural que é considerada como pressuposto indispensável à reflexão teológico-filosófico-jurídica. 0 direito natural cristão encontrou seu fundamento filosófico na doutrina estóica da ordem divina do mundo, segundo a qual o universo é governado pelos deuses ou pelo logos. 0 homem é parte do universo. Santo Agostinho descreve o mundo como um sistema articulado hierarquicamente. Ele ainda acrescenta que há uma lei eterna à qual estão ordena-

\footnotetext{
XVII. Sob a denominação de «escola do direito natural» encontram-se autores e correntes muito diferentes e até opostas, representadas pelos grandes filósofos políticos Hobbes, Leibniz, Locke, Rousseau, Kant e por juristas filósofos como Pufendorf, Thomasius e Wolf.

2 Cf. EUCHNER, W., La Filosofia Politica di Locke, Traduzione di Katja Tenembaum, Laterza, Roma-Bari, 1995, 7-15.

3 Ibid., 23.

${ }^{4}$ Cf. ARISTÓTELES, Ética a Nicômaco, tradução de Leonel Vallandro e Gerd Bornheim, Nova Cultural, 1987, Livro V, cap. VII, 1134b, 91.

${ }^{5}$ Cf. Id., Retorica, in Opere, Vol. X, Laterza, 1973, 1375 a, 58.
} 
das todas as coisas e da qual a lei temporal extrai toda a sua força mediante a participação.

\begin{abstract}
"Aquela lei que é chamada a Razão suprema de tudo, [...] a noção impressa em nosso espírito dessa lei eterna, direi que ela é aquela lei em virtude da qual é justo que todas as coisas estejam perfeitamente ordenadas [...]. E tal lei superior é a única sobre a qual todas as leis temporais regulam as mudanças a serem introduzidas no governo dos homens [...]"6.
\end{abstract}

Todos os seres são dotados de um comportamento conforme a ordem da criação planejada e realizada por Deus. Portanto, o logos da doutrina estóica que governa o Cosmo torna-se a lex aeterna que está presente em toda a criação e determina o agir de todas as coisas, enquanto se identifica com a razão ou vontade divina ${ }^{7}$. Então, a ordem que Deus quer que reine na natureza humana está fundamentada na lei eterna e exige subordinação das paixões à razão.

A doutrina jusnaturalista de São Tomás de Aquino, cuja base de desenvolvimento é a doutrina aristotélica, adquire a máxima relevância ao afirmar que todas as criaturas aspiram à condição da perfeição divina. A natureza é o universo da criação divina governada pela lei eterna de Deus. As coisas estão inseridas numa ordem cósmica. 0 homem, como parte da criação, participa da lex aeterna. "E esta participação da lei eterna na criatura racional é o que se chama lei natural" (participatio legis aeternae in rationali creatura $^{8}$. Embora 0 instinto de conservação do homem sirva de base para a doutrina do direito natural, segundo o jusnaturalismo estóico-escolástico, esse instinto está inserido na hierarquia dos fins, orientado à participação da razão divina.

Segundo os estóicos, o instinto e a razão são duas forças infalíveis da conservação da ordem perfeita do Cosmo. A alma é comparada a uma tabula rasa, na qual são inscritos sinais das virtudes naturais. 0 instinto de conservação e as virtudes superiores que se desenvolvem sob a coordenação da razão constituem princípios do dever. As virtudes estão em conformidade com o viver segundo a natureza 9 .

$\mathrm{Na}$ teoria jusnaturalista clássico-medieval, o homem, em sua individualidade, tem capacidade de conhecer as normas naturais objetivas porque participa do logos ou da lex aeterna que governam o Cosmo, pois na

\footnotetext{
${ }^{6}$ AgOSTINHO, O Livre Arbítrio, Livro I, 6,15, tradução de Nair de Assis Oliveira, Paulus, São Paulo, 1995, 41-42.

${ }^{7}$ AGUSTIN, Contra Fausto, XXII, 27, in Obras completas de San Agustin, XXXI, Escritos Antimaniqueos $\left(2^{\circ}\right)$, BAC, Madrid, 1993, p.540. Não é nosso objetivo abordar o problema amplamente discutido na Escolástica, se a lei natural e eterna seja expressão da vontade divina (nominalistas) ou expressão da razão eterna de Deus (realistas).

8 TOMAS DE AQUINO, Suma de Teologia, vol. 2, I-II, q. 91, a.2, BAC, Madrid, 1997.

${ }^{9}$ Cf. EUCHNER, W., La Filosofia Politica di Locke., 28-29.
} 
natureza humana age o logos objetivo ou a razão divina. Santo Agostinho retoma a doutrina estóica dos logoi spermatikoi em sua proposta gnosiológica e apresenta a doutrina da iluminação como ação de Deus sobre a mente humana como condição indispensável ao homem para a aquisição do conhecimento. Deus ilumina a inteligência e a vontade para que o homem possa conhecer as verdades eternas (ratio superior) e as verdades mutáveis (ratio inferior) ${ }^{10}$. Com a iluminação divina, o homem pode conhecer as determinações da lei natural. Santo Agostinho afirma também que a "noção da lei eterna está impressa em nós"11.

São Tomás diz que "toda criatura racional conhece a lei eterna por sua irradiação mais ou menos perfeita, pois todo conhecimento da verdade é irradiação e participação da lei eterna, que é a verdade imutável"12. Ora, a capacidade do homem de conhecer os princípios do direito natural é guiada por uma inclinação inata denominada de synderesis ${ }^{13}$. A razão humana não é arbitrária, pois ela traz consigo os princípios do direito natural como luz natural e como iluminação da lei eterna, de tal modo que no homem está presente uma aspiração natural à perfeição.

0 direito natural estóico referindo-se à força vinculante da lei natural sobre a ação humana diz que o homem encontra em sua própria natureza o critério de sua ação moral e tal critério de ação coincide com a conveniência cósmica. Reconhecer o dever que provém do direito natural é condizente com a sua própria natureza; por isso, agir de modo contrário a este implica punição. Os escolásticos assumem esta doutrina estóica do direito natural ao afirmarem que a lei natural possui um caráter implícito de dever, porque Deus é o legislador e porque o homem participa da lei eterna com sua inclinação ao bem e à justiça. Assim, o agir contrário à lei natural implica castigo ou punição por parte de Deus ${ }^{14}$. Para São Tomás, as leis possuem duas funções específicas em relação aos atos maus: proibir ao homem de fazer 0 mal e castigar a quem comete delito15. Embora, à primeira vista, a lei se apresente apenas como via coercitiva, contudo,

${ }^{10}$ Cf. AGOSTINHO, Confissões, VII, 10,16, tradução de J . Oliveira Santos e A. Ambrósio de Pina, Nova Cultural, São Paulo, 2004. Também La Città di Dio XII,7,12, traduzione di Domenico Gentili, Città Nuova, Roma, 1997, 602-3.

${ }_{11}^{11}$ AGOSTINHO, O Livre Arbítrio, Livro I, 6,15, p.41.

12 TOMÁS DE AQUINO, Suma de Teología, BAC, Madrid, 1997, vol. 2, I-II, q. 93, a.2. 13 “(...) synderesis dicitur lex intellectus nostri, inquantum est habitus continens praecepta legis naturalis, quae sunt prima principia operum humanorum", in Summa Theologiae, la Il ae, quaest. 94, art., 1.

${ }^{14}$ A doutrina jusnaturalista escolástica se divide em duas correntes antagônicas: nominalismo e realismo. O nominalismo (representado principalmente por Duns Scoto, Guilherme de Ockham) defende que a lei natural é apenas como um comando de Deus. Uma parte do jusnaturalismo espanhol (Francisco Vitoria, Ludovico Molina e Gabriel Vasquez ) defende que as normas objetivas são vinculadas a Deus.

${ }^{15}$ Cf. TOMAS DE AQUINO, Suma de Teologia, vol. 2, I-II, q. 92, a.2. 
segundo o jusnaturalismo tomista, a lei é, sobretudo, a via diretiva, visto que orienta o homem a agir segundo as virtudes.

$\mathrm{Na}$ doutrina tradicional aristotélico-tomista, o homem é considerado um animal social e político (Naturale autem est homini ut sit animal sociale et politicum ${ }^{16}$; por isso, o viver em sociedade é inerente à própria natureza do homem como animal não dotado de especialização biológica, já que para sobreviver necessita da vida social como uma ação de mútua ajuda, e não apenas por uma mera necessidade convencional de um contrato social. A vida social é, então, expressão de sua carência de especialização biológica e, ao mesmo tempo, de sua natureza racional que o faz artífice de sua existência frente às dificuldades naturais.

O Estado, segundo São Tomás, tem como fim o Bem Comum. E as suas leis visam não apenas à sobrevivência dos indivíduos, mas ao desenvolvimento da vida virtuosa de cada indivíduo ${ }^{17}$. Quando as leis positivas não são expressão da lei eterna e não são reconhecidas como conformes à reta razão, então não obrigam o homem em consciência, visto que as leis positivas para serem válidas devem ser também justas, isto é, de acordo com a lei natural ${ }^{18}$.

\section{Doutrina moderna do direito natural}

A doutrina jusnaturalista moderna, não-escolástica e antiaristotélica, caracteriza-se pela tentativa de conciliação entre a visão de um mundo harmonioso criado por Deus e uma concepção individualista do homem.

Ora, o modo de produção capitalista possibilitou que o indivíduo saísse da ordem corporativista fechada do sistema feudal para um mundo mercantilista no qual o homem é um agente livre dotado de direitos particulares. Abandonou-se, portanto, a visão cosmopolita do homem como parte de um universo criado por Deus e hierarquicamente ordenado. Além disso, o desenvolvimento da ciência moderna e a filosofia da natureza de cunho mecanicista causaram dificuldades de compreensão quanto à doutrina tradicional da participaçãa ${ }^{19}$. No sistema jusnaturalista escolástico, 0

\footnotetext{
${ }^{16}$ THOMAE AQUINATIS, De regimine principum, J oseph Mathis curante, Taurini, 1924, 2.

${ }_{17}$ Cf. TOMAS DE AQUINO, Suma de Teologia, vol. 2, I-II, q. 96, a.1.

18 Ibid., q. 95 , a. 2 ; q. 96, a. 4.

19 Para Platão, a doutrina da participação consiste na relação entre as idéias e o mundo sensível. As idéias são a causa, o princípio das coisas. E a relação entre as idéias e as coisas pode ser de participação, imitação, comunhão e presença: participando da idéia a coisa realiza a própria essência. Para Tomás de Aquino, a doutrina da participação é um recurso para distinguir o ser de Deus (ens per essentiam) do ser das coisas (ens per participationem).
} 
valor do direito natural coincidia com a razão divina; contudo, no jusnaturalismo moderno, os princípios do direito natural do homem não fazem parte da razão divina enquanto lex aeterna. 0 homem não se considera inserido na ordem cósmica da criação com toda a sua dimensão racional e instintiva modelada pela lex aeterna.

Pelo contrário, o indivíduo centra-se em si mesmo, em seu potencial racional e instintivo derivado de suas faculdades naturais. 0 homem não é uma criatura que age conforme um modelo determinado pela vontade de Deus correspondente à ordem natural, como as outras criaturas; mas o indivíduo deduz os princípios de sua ação segundo uma estrutura autônoma inerente ao próprio homem ${ }^{20}$. 0 direito natural não é derivado da ordem da criação permeada pela razão divina, uma vez que a doutrina jusnaturalista moderna parte do instinto de conservação e 0 exalta como fundamento do direito natural inerente à natureza racional e instintiva do homem. Sendo assim, a sociabilidade humana não é uma tendência espontânea posta por Deus nos homens, mas a vida em sociedade está vinculada ao instinto individualista de conservação.

A teoria do conhecimento jusnaturalista moderno não aceita a existência de princípios inatos, ou seja, a priori, do direito natural, nem tampouco de "sementes do logos" impressas na natureza humana. O direito natural se desenvolve a partir do esforço autônomo da razão. 0 verdadeiro meio de conhecimento do direito natural é a experiência sensível vinculada à razão instrumental. A dedução de princípios das normas do direito natural provém da própria natureza humana ${ }^{21}$. Hobbes $^{22}$, como representante do jusnaturalismo moderno, busca delinear uma concepção de natureza humana que seja comum a qualquer homem e em qualquer circunstância, segundo a qual o homem vive em uma luta recíproca pelo poder em função de sua própria conservação.

O jusnaturalismo moderno dá grande ênfase ao caráter coercitivo da lei. Uma vez que os modernos não concebem a estrutura humana como dotada de um valor normativo coerente com o Cosmo ou com a vontade de Deus, faz-se necessário que a força coercitiva das leis decorra de uma autoridade legisladora ou da própria subjetividade da razão humana. Para Hobbes, o homem deve adequar suas ações às prescrições vindas de uma autoridade legisladora externa e superior. A ação do homem pode ser considerada justa ou injusta se estiver em conformidade ou desconformidade com as leis decretadas pelo monarca que detém o poder de legislar.

${ }^{20}$ Cf. EUCHNER, W., La Filosofia Politica di Locke, 25-26.

21 Ibid., 33.

${ }^{22}$ Cf. HOBBES, T., Leviatã (ou Matéria, Forma e Poder de um Estado Eclesiástico e Civil), tradução de Alex Marins, Martin Claret, São Paulo, 2002. Veja-se aí a posição hobbesiana sobre a lei natural (caps. XIV e XV), sobre os direitos dos soberanos (cap. XVIII) e sobre a liberdade dos súditos (cap. XXI). 
Kant fala, sem dúvida, da universalidade da lei, mas enquanto desvinculada de Deus e da ordem cósmica, de modo que o dever que vincula a ação humana não provém de um legislador externo, mas é intrínseco à própria razão humana ${ }^{23}$.

$\mathrm{Na}$ doutrina jusnaturalista moderna, a sociabilidade é um artifício indispensável aos indivíduos que tendem por sua própria natureza a viver isolados. A vida social nasce a partir de um contrato entre os diversos indivíduos a fim de tornar possível a convivência social. Por isso, os indivíduos se reúnem em uma sociedade política (Estado) apenas com a finalidade de sobrevivência. Para Hobbes ${ }^{24}$, os indivíduos renunciam aos direitos naturais (exceto à vida) quando entram no Estado Civil. A partir do consenso eles transferem os direitos naturais ao monarca como detentor de um poder absoluto a fim de garantir uma vida social que Ihes traga segurança. Ele defende que o soberano não tem nenhum dever em relação aos súditos e estes não têm nenhum direito à resistência contra o poder soberano. 0 critério de justiça ou injustiça nasce da vontade do rei expressa nas leis civis, mesmo que não haja uma correspondência entre a lei civil e a lei natural. Enquanto o jusnaturalismo tradicional defendia a supremacia da lei natural em relação à lei civil, quando esta última estava em discordância com aquela primeira; o jusnaturalismo moderno, ao contrário, defende a superioridade do direito positivo sobre o direito natural.

\section{Doutrina lockiana do direito natural}

Após a apresentação das características gerais das doutrinas do direito natural, em sua acepção tradicional e em sua acepção moderna, será mais fácil compreender os elementos convergentes e divergentes da doutrina do direito natural (clássica ou moderna) na elaboração teórica de Locke.

Locke, em sua doutrina do direito natural, concorda geralmente com a doutrina tradicional quando distingue três tipos de lei: lei divina, lei civil e lei de costume. A lei divina pode ser positiva e natural. 0 homem só pode conhecer a lei divina positiva diretamente através da revelação feita por Deus. Contudo, a lei natural pode ser conhecida pelo homem indiretamente mediante a razão ou "luz natural" 25 . No jusnaturalismo escolástico-

${ }^{23}$ Cf. VV.AA. Os Filósofos através dos Textos - De Platão a Sartre - São Paulo: Paulus, 1997, 184-5.

${ }^{24}$ No Leviatã Hobbes afirma que as leis do estado de natureza não são observadas na íntegra pelos indivíduos e nem tampouco são válidas no estado civil, bem como que os soberanos têm o direito de criar as leis civis e de interpretar as leis naturais conforme Ihes for conveniente, cap. XXVI, 196-213.

${ }^{25}$ Cf. LOCKE, J ., Segundo Tratado sobre o Governo, tradução de E. J acy Monteiro, Abril Cultural, Sâo Paulo, 1978, 45. 
tomista, a lei eterna coincide com a razão divina, por isso, o homem não pode conhecê-la plenamente, mas a conhece por participação, na sua representação que é a lei natural. Na doutrina lockiana, ao contrário, a lei eterna equivale à lei natural, visto que ele não reconhece a doutrina da participação ${ }^{26}$. A lei natural detém um caráter ético-político, já que orienta a vida não só dos súditos, mas também dos soberanos.

Na Carta acerca da Tolerância e no Segundo Tratado sobre o Governo, Locke pressupôs o direito natural como um dado factual e reconhecido pela razão humana, por isso, não se deteve a explicá-lo. Todavia, nos Ensaios sobre a lei natura ${ }^{27}$, encontra-se uma análise minuciosa das normas da lei natural. Locke demonstra a existência da lei natural, examina as fontes de conhecimento das normas do direito natural, afirma o caráter obrigatório da obediência às normas derivadas do direito natural.

A existência da lei natural é deduzida do caráter teleológico de todos os seres: as plantas, os animais e o homem vivem segundo leis imutáveis que operam conforme a natureza de cada ser, pois "existe uma natureza divina que governa o mundo"28. Deus ordenou, segundo a sua vontade e sabedoria, as coisas a um fim proporcional a cada espécie. No universo existe uma lei natural criada por Deus que serve de norma diretiva para a vida do homem. Isto possibilita que a razão humana reconheça a virtude ou 0 vício das ações do homem. A "reta razão" e a "lei da natureza" são expressões empregadas por Locke como sinônimas para exprimir o fundamento do dever do agir moral. E este dever consiste em viver conforme a própria natureza. A lei natural é uma "disposição da vontade divina, cognoscível por meio da luz natural do intelecto" ${ }^{29}$. À medida que o homem age em conformidade ou desconformidade com a natureza racional, a lei natural expressa uma ordem ou uma proibição. 0 homem não é 0 autor da lei natural, mas o seu intérprete.

0 pensamento lockiano está predominantemente de acordo com a tradição aristotélico-tomista quando se refere à existência da lei natural que rege as criaturas como manifestação da inteligência e da vontade de Deus que criou todas as coisas para um fim específico.

\footnotetext{
${ }^{26}$ Cf. EUCHNER, W., La Filosofia Politica di Locke, 25-27.

${ }^{27}$ Os "Essays on the Law of Nature" foram escritos em latim nas formas tradicionais das discussões acadêmicas aproximadamente entre 1660 e 1664, e não foram nunca publicados por Locke. Foram conservados na "Lovelace Collection" que recolhe todos os manuscritos lockianos e somente em 1954 W. von Leyden fez a primeira edição crítica. Serão citados segundo a tradução italiana: Saggi sulla Legge naturale, traduzione di Marta Cristiani, Laterza, Roma-Bari, 1996.

${ }^{28}$ LOCKE, J., Saggi sulla Legge naturale, 3.

${ }^{29}$ LOCKE, J., Saggi sulla Legge naturale, 5.
} 
Ele apresenta cinco argumentos a fim de demonstrar a existência da lei natural ${ }^{30}$. As idéias básicas desses argumentos são: a) todas as coisas exercem uma atividade específica inerente à sua própria natureza. $\mathrm{E}$ a atividade própria do homem é o dever de agir segundo a razão ${ }^{31}$, por isso, 0 direito natural tem uma validade universal ${ }^{32}$; b) todos os homens são dotados de uma faculdade moral que Ihes permite confrontar as suas ações com a sua própria consciência, e 0 emitir juízo de inocência ou de culpabilidade de seus atos só é possível devido à existência da lei natural; c) a partir da estrutura cósmica se deduz que há uma lei que estabelece o modo de ser de todas as coisas, pois "todas as coisas criadas estão sujeitas à lei eterna" ${ }^{3}$. 0 homem por ser uma criatura dotada de faculdades cognitivas especiais tende a um grau de maior perfeição em seu agir; d) o vínculo social existente entre os indivíduos é regido por leis derivadas de um pacto. Isto só será possível a partir de uma lei natural válida universalmente para todos os homens (governantes e governados) evitando, desta forma, ações arbitrárias; e) as noções de virtude e de vício só são possíveis à proporção que existe uma lei natural como referência ao agir humano. A existência da lei natural torna "eterna e imutável a natureza do bem e do mal"34.

Locke se distancia da tradição aristotélico-escolástica quando analisa as fontes do conhecimento da lei natural. Ele analisa as três fontes tradicionais do conhecimento da lei natural: a inscrição (inscriptio), a tradição (traditio) e o consenso (consensus). A inscrição é a doutrina segundo a qual a lei natural é conhecida mediante os primeiros princípios do direito natural que são impressos por Deus na alma humana. Ele nega essa doutrina porque "a alma humana no momento do nascimento é uma tabula rasa". Argumenta que se a lei natural fosse efetivamente inscrita na alma humana não existiriam divergências quanto a esta questão. É verdade que, segundo alguns, esta lei inscrita no homem foi cancelada parcialmente da memória com o pecado, enquanto, segundo outros esta lei da natureza foi cancelada totalmente com 0 pecado ${ }^{35}$. Locke responde que, se essa lei fosse inscrita na razão humana, deveria haver um acordo ao menos parcial, mesmo depois do pecado. Outra objeção levantada por ele a essa doutrina consiste em afirmar que se a lei fosse inscrita na alma do homem, as crianças que não atingiram o uso da razão, os loucos, os povos primitivos seriam dotados de princípios morais inatos. Isto, porém, não corresponde à realidade ${ }^{36}$.

\footnotetext{
30 Ibid., 3-13.

${ }^{31}$ Cf. ARISTÓTELES, Ética a Nicômaco, I,7,14, 1098a, tradução de Leonel Vallandro e Gerd Bornheim, Nova Cultural, 1987.

32 Ibid., V,7,1,1134b.

${ }_{33}$ Cf. TOMAS DE AQUINO, Suma de Teologia, vol. 2, I-II, q. 93, a.4..

${ }^{34}$ LOCKE, J., Saggi sulla Legge naturale, 13.

${ }^{35}$ Embora Locke não explicite nenhum nome, é provável que esteja argumentando contra as doutrinas do pecado original de Agostinho, de Calvino e de Lutero.

${ }^{36}$ Cf. LOCKE, J., Saggi sulla Legge naturale, 28-30.
} 
Quanto à tradição, ele considera esta forma de conhecimento repleta de contrastes, por isso, ela não constitui uma fonte segura para o conhecimento do direito natural. A existência de grande variedade de tradições em conflito possibilita que cada um escolha a verdade segundo a própria opinião, pois a apreensão da lei pela tradição é mais um ato de fé do que um ato de conhecimento, já que a dependência de uma autoridade prevalece sobre a evidência da coisa em si. Analisar criticamente a tradição e firmar-se numa tradição já não é propriamente conhecer pela tradição. Trata-se neste caso de um conhecimento pela argumentação ou pela percepção dos sentidos ${ }^{37}$.

0 consenso está vinculado à tradição mediante o conhecimento da lei natural, porque em ambos os casos o conhecimento se identifica com a aceitação de dados pré-existentes. Locke exclui de sua refutação o consenso positivo (consensus positivus), resultante do contrato, que cria exclusivamente normas positivas, não normas naturais. 0 direito natural referese somente ao consenso natural (consensus naturalis). 0 consenso natural refere-se aos hábitos e às ações morais, às opiniões geralmente aceitas e ao reconhecimento dos princípios práticos ${ }^{38}$. Em geral, o consenso não representa uma prova da lei natural, porque a conduta dos homens demonstra uma variedade de vícios (corrupção e crime). Não existe um consenso universal a respeito da retidão moral, pois as normas morais são relativas aos diversos contextos histórico-culturais, possibilitando conflitos de valores. Certas ações morais que são proibidas em determinados contextos, são lícitas em outros contextos ou até incentivadas na sua prática. Portanto, não há um consenso universal dos homens referente aos princípios práticos do agir moral; por isso, o consenso não pode ser fonte de conhecimento seguro da lei natural ${ }^{39}$.

Depois de haver demonstrado a ausência de validade da inscriptio, traditio e consensus como fontes seguras do conhecimento do direito natural, Locke diz que a experiência sensível é a única via segura para a razão humana conhecer a lei natural (sensus), uma vez que "a alma é, no momento do nascimento do homem, uma tabula rasa" ${ }^{40}$. A lei natural não se apresenta como algo evidente à experiência sensível, no entanto, os sentidos oferecem a matéria sensível para que a razão possa examinar os princípios do conhecimento da lei natural. 0 princípio fundamental que exerce a função

\footnotetext{
${ }^{37}$ LOCKE, J ., Saggi sulla Legge naturale, 20-22.

${ }^{38} \mathrm{Um}$ estreito vínculo entre o Ensaio sobre o Entendimento Humano e os escritos juvenis lockianos.(os Ensaios sobre a Lei Natural e os Tratados sobre o Magistrado Civil) mostra-se na crítica das idéias inatas, sobretudo no que se refere à ausência de um consenso universal. Nesses escritos, Locke se aproxima muito da concepção hobbesiana sobre a incapacidade dos indivíduos de viverem com segurança a partir de um consenso natural e da ausência de um vínculo progressivo entre o direito natural e o direito positivo.

${ }^{39}$ Cf. LOCKE, J ., Saggi sulla Legge naturale, 48-49.

40 Ibid., 27. Confira também o capítulo II do Livro I do Ensaio sobre o Entendimento Humano, onde Locke afirma que não há princípios inatos na mente humana.
} 
de um primum principium na filosofia lockiana do qual derivam os princípios do direito natural é a relação do homem com Deus. Deus é um legislador que estabelece que cada coisa opere segundo a sua natureza. Sendo assim, Deus criou o homem dotado de faculdades cognoscitivas (sentidos e intelecto) a fim de que o homem possa garantir a sua sobrevivência na ordem da criação.

Todas as coisas criadas por Deus são dotadas de finalidade. Por isso, os sentidos e 0 intelecto são faculdades cognitivas que visam ao conhecimento dos princípios da lei natural. 0 homem ao usar suas faculdades cognitivas descobre a existência de uma divindade suprema e se sente impulsionado a organizar suas relações com os outros homens a partir do instinto de conservação. Por isso, "os deveres dos homens em relação a Deus, ao próximo e a si mesmo"41 derivam do instinto de autoconservação. Locke, contrariamente à tradição, não considera a razão um princípio prático e estruturado de modo a priori em sentido normativo. Ela é uma facultas, faculty, um instrumento que nos permite conhecer ${ }^{42}$.

Tanto o jusnaturalismo tradicional quanto o jusnaturalismo moderno afirmam que as normas da lei natural possuem um caráter de obrigação que procede do comando jurídico de Deus. Todavia, a diferença entre a tradição e a modernidade quanto ao dever que provém da lei natural consiste em que os modernos dão maior ênfase à força coercitiva procedente do comando de Deus como legislador que aplica punições aos transgressores, enquanto os tradicionais dão maior relevância à força diretiva já que o homem participa da lei divina.

A tese de Locke sobre o dever obrigatório de agir segundo a lei natural é semelhante à tese da tradição quando afirma que a lei natural obriga porque é comandada por Deus e porque a sua transgressão impede ao homem de ser feliz. Toda obrigação derivada da lei da natureza tem Deus como seu fundamento último. Por isso, há dois tipos de deveres ${ }^{43}$ : a) aqueles que derivam da sabedoria divina do legislador e do direito que possui o Criador em sua relação com a criatura (debitum officii); b) aqueles que derivam do poder de punição quando a ação não está em conformidade com o dever da consciência (debitum supplicii). Segundo a doutrina lockiana, a lei natural resulta de um dever obrigatório porque Deus a promulgou com sabedoria e deu ao homem capacidade de conhecê-la através da luz natural. Uma vez que o ser e o operar do homem dependem da vontade de Deus, então, cabe ao homem o dever de agir conforme a vontade suprema do legislador divino. O legislador divino tem o poder de punir o transgressor posto que o homem tem a capacidade de reconhecer a autoridade de Deus em sua consciência.

${ }^{41}$ LOCKE, J ., Saggi sulla Legge naturale, 44.

${ }^{42}$ LOCKE, J., Saggi sulla Legge naturale, 36-37.

43 I bid., 62-63. 
Locke, tal como a tradição, sustenta que o poder vinculante da lei da natureza é eterno e universalmente válido. Em qualquer época e em qualquer contexto histórico, os homens estão obrigados a viver segundo as prescrições da lei natural porque estes vínculos nasceram com 0 gênero humano e permanecerão até quando ele existir. A obrigação derivada da lei natural é imutável, entretanto, mudam-se as circunstâncias. Por isso, existem três tipos de vínculos de obrigação ${ }^{44}$ : a) há coisas que são sempre proibidas ou prescritas (o furto, o homicídio, a veneração a Deus, o amor aos pais e ao próximo); b) há outras coisas, porém, a que não estamos obrigados sempre, mas somente em um determinado momento e em um determinado modo (consolar um vizinho em luto ou nutrir um homem que se encontra necessitado); c) há coisas a que não somos obrigados em absoluto, mas somente em modo condicionado (nenhum é obrigado a ser amigo dos próprios vizinhos).

Segundo Locke, a lei natural apresenta um caráter de obrigatoriedade, de universalidade e de cognoscibilidade.

"Já que todos os homens são por natureza racionais, e subsiste uma concordância entre esta lei e a natureza racional, concordância que é cognoscível graças à luz natural, é necessário que todos que são dotados de uma natureza racional, isto é, todos os homens de qualquer maneira, estejam obrigados à observância desta lei $[. . .]^{\prime \prime 4}$.

Locke, portanto, fundamenta a sua doutrina da obrigação da lei natural recorrendo à doutrina clássica da concordância recíproca da natureza racional do homem com a lei natural. A retidão de uma ação humana não depende "da utilidade, se bem que a utilidade é a conseqüência da retidão"46. 0 homem que busca a própria felicidade age de acordo com a lei natural à medida que concilia 0 interesse particular com 0 dever proveniente do direito natural.

- Ensaio acerca do Entendimento Humano e os Pensamentos sobre a Educação apresentam uma diferença entre "obrigação" e "motivação da vontade" do agir humano.

No Ensaio acerca do Entendimento Humano, Locke apresenta uma idéia do bem e do mal coerente com a lógica do empirismo e com a redescoberta da teoria hedonista:

"[...] 0 bem e o mal nada mais são do que prazer ou dor, ou o que ocasiona ou provoca em nós o prazer ou a dor. 0 bem e o mal morais consistem, pois, apenas no acordo ou desacordo das nossas ações voluntárias com certa lei pro meio da qual o bem e o mal são impostos pela vontade e pelo poder do legislador. 0 bem e o mal, ou o prazer ou a dor, implicando nossa

\footnotetext{
44 I bid., 72-73.

45 Ibid., 75-76.

${ }^{46}$ LOCKE, J., Saggi sulla Lege naturale, 90.
} 
obediência ou nosso rompimento com a lei decretada pelo legislador, são o que denominamos prêmio e castigo" ${ }^{47}$.

0 bem ou o mal não são idéias absolutas, mas relativas à conformidade ou à discordância das ações voluntárias do homem com a lei. A teoria da motivação do agir humano consiste substancialmente em que " $O$ limite da magnitude dos prazeres é o afastamento de toda a dor" ${ }^{48}$. A felicidade é definida como busca do prazer e fuga da dor. Sendo assim, em Locke, como em Epicuro somente o medo da punição e a busca do prazer afastam 0 homem da ação injusta.

Nos Pensamentos sobre a Educação, Locke manifesta que aquilo que determina a ação humana é a vantagem que recai sobre o próprio agente uma vez que tal comportamento é "absolutamente necessário" para "tornar-se amado e estimado pelos outros" ${ }^{49}$. Ele defende também a idéia de que a felicidade coincide com o prazer.

"[...] A felicidade à qual os homens constantemente aspiram consiste no prazer. [...] A capacidade, a seriedade e as boas intenções de um homem importante e de valor [...] dificilmente compensam o mal-estar (uneasiness) que causa o seu comportamento sério e ponderado. Poder e riqueza, até a própria virtude são estimados somente porque contribuem à nossa felicidade $[\ldots]^{350}$.

Locke se distancia da doutrina tradicional quanto à motivação do agir humano visto que os homens não estão obrigados à lei natural só porque a sua consciência deduz que algo é justo, mas também devido ao prazer e à felicidade a que cada homem aspira. "Esta disposição do homem ao agir só pela busca do prazer faz da recompensa e da pena um elemento insubstituível do sistema jusnaturalista lockiano" ${ }^{51}$. 0 fundamento formal da obrigação da lei é a vontade justa de Deus, mas a motivação do agir humano é a própria felicidade entendida como a maximização do prazer através da fuga da dor.

Bobbio mostra com precisão as diferenças fundamentais que caracterizam o jusnaturalismo tradicional e o jusnaturalismo moderno.

"Ora tanto a idéia da lei como comando sancionado, quanto a teoria hedonista da ética são estranhas à tradição jusnaturalista, a qual, ao contrá-

\footnotetext{
47 Id., Ensaio acerca do entendimento Humano, Tradução de Anoar Aiex e E. J acy Monteiro, São Paulo, Abril Cultural, 1978, 215.

${ }^{48}$ EPICURO, Antologia de Textos, tradução de Agostinho Sicro, São Paulo, Abril Cultural, 1973, 22.

${ }^{49}$ Cf. LOCKE, J., Some Thoughts concerning Education, Oxford, Oxford Univ. Press, 1989. Citado segundo a tradução italiana, Pensieri sull'Educazione, La Nuova Italia, Firenze, 1989, 181.

50 Ibid. 191-192.

51 EUCHNER, W., La Filosofia Politica di Locke, 208.
} 
rio, prefere definir a lei como doutrina da reta razão (e prescinde completamente do conceito de sanção), e por outro lado, entende poder derivar as leis da conduta humana de um tipo de bem mais permanente, objetivamente determinável e observável, que não os sentimentos de prazer e de dor, isto é, das inclinationes ou tendências do homem" ${ }^{52}$.

Em suma, pode-se dizer que a doutrina lockiana do direito natural é uma posição que mescla tanto elementos do jusnaturalismo tradicional quanto do jusnaturalismo moderno. Não é possível classificar os seus escritos juvenis como pertencentes à doutrina tradicional, nem tampouco classificar os escritos da maturidade como pertencentes à doutrina moderna, pois tanto estes como aqueles apresentam elementos de ambas as doutrinas. Ora, isto torna difícil sustentar que a doutrina do direito natural lockiana pertença exclusivamente à ética estóica ou à ética epicurista. A posição mais plausível é que em sua doutrina se encontram ambos elementos que serão instrumentos na elaboração dos direitos naturais dos indivíduos como pressupostos da delimitação do poder político.

\section{II - Os direitos naturais}

O estado de natureza é uma categoria utilizada pelos contratualistas para indicar um estado da história da humanidade anterior ao estabelecimento da sociedade civil ou política. Uma compreensão correta da origem do poder político depende do conhecimento prévio de como viviam os homens antes de formar a sociedade política. Segundo Locke, no estado de natureza, os homens gozam de direitos regulados pela lei da natureza. Os direitos naturais prioritários são: a autoconservação, a liberdade e a propriedade.

\section{0 direito à autoconservação}

O homem é uma criatura especial da obra criadora de Deus. Deus o criou dotado de faculdades cognoscitivas para que o homem pudesse conhecer as coisas e usufruir delas conforme as suas necessidades vitais. Deus colocou todas as coisas criadas à disposição do homem visando não só à sua conservação, mas também a uma vida feliz. Viver feliz consiste em usar os bens materiais (alimentação, vestuário, moradia, medicina) da melhor forma produtiva e racional. As riquezas naturais criadas por Deus são as condições de uma existência humana mais cômoda possível.

52 BOBBIO, N., Locke e I/ Diritto Naturale, Giappichelli, Torino, 1963, 164. 
"Uma vez que Deus fez o homem e Ihe implantou, como qualquer animal, um forte desejo de autoconservação, e forneceu o mundo de coisas adequadas à nutrição, ao vestuário e a outras necessidades da vida [...]. Deus, então, depois de haver criado o homem e o mundo, Ihe falou, isto é, se dirigiu ao homem através dos seus sentidos e de sua razão, como se dirigiu, através dos sentidos e do instinto, aos animais inferiores, que eram úteis à subsistência do homem e dados a ele como meios da sua conservação" ${ }^{53}$.

Observa-se que 0 instinto de conservação comum a todo o gênero animal recebe uma conotação especial quando se refere à espécie humana: o homem deve usar o seu potencial racional para conhecer as coisas da natureza em prol do seu bem-estar. Conhecer significa utilizar a capacidade de manipular as coisas naturais em benefício próprio. As faculdades cognitivas do homem são direcionadas a uma práxis que lhe permite viver em condições dignas. 0 homem deve usar todas as forças físicas e mentais como instrumentos de realização de uma vida feliz.

0 princípio prático e fundamental da autoconservação é um direito que assiste a todos os homens. Por isso esse direito implica um dever: conservar a própria vida requer conservar também a vida do outro, quando isto não põe em risco a própria vida. Tanto o jusnaturalismo tradicional quanto o jusnaturalismo lockiano afirmam que as criaturas são propriedades de Deus. Em Locke, a autoconservação como direito fundamental do homem não pode ser entendida em sentido individualista, visto que ele sustenta a responsabilidade do indivíduo pela conservação da vida do outro. Deus como autor da lei natural aspira à conservação não só do indivíduo particular, mas também de toda a humanidade.

Os instintos, assim como a racionalidade, visam à conservação da espécie humana. Assim o instinto sexual é a possibilidade da autoconservação a partir da conservação da espécie: "Deus na sua infinita sapiência pôs na natureza humana fortes desejos de copulação para perpetuar assim a raça humana, o que ele faz na quase totalidade dos casos fora da intenção e sempre contra o consentimento e a vontade de quem gera" ${ }^{54}$.

Em Locke, 0 instinto da conservação $0^{55}$ aparece como único princípio inato no homem. Deste instinto de perpetuação da espécie dado por Deus ao homem deriva 0 direito de autoconservação através da própria descendência.

A importância atribuída à autoconservação como princípio prático fundamental é posta em grande evidência no Segundo Tratado quando Locke fala da liberdade e da propriedade como pressupostos essenciais da autoconservação e sobretudo quando se opõe ao poder absoluto do Estado

53 LOCKE, J., Segundo Tratado sobre o Governo, 36.

${ }^{54}$ LOCKE, J ., Segundo Tratado sobre o Governo, 55-56.

55 No Segundo Tratado sobre o Governo, Locke fala do instinto de autoconservação como princípio prático inato; contudo, nos Ensaios sobre a Lei Natural ele nega que seja possível considerá-lo como fundamento da lei natural. 
em confronto com os direitos dos indivíduos ${ }^{56}$. A liberdade e a propriedade estão a serviço da autoconservação. Portanto, o indivíduo que viola esse direito pode vir a perder a própria vida, já que ao transgredi-lo está se declarando inimigo da comunidade humana. 0 Estado, por sua vez, transgride 0 direito à conservação quando não respeita às leis estabelecidas pelo consenso. Por conseguinte, o Estado poderá ser destituído uma vez que a sua finalidade é proteger os direitos dos indivíduos existentes no estado de natureza. 0 direito da autoconservação é, segundo a doutrina lockiana, um princípio que rege toda a experiência da existência individual e social.

\section{0 direito à liberdade}

O estado de natureza se caracteriza por dois estágios: no primeiro, a maioria dos homens vive conforme a lei da razão; no segundo, os homens vivem dominados pelos interesses egoístas, numa situação semelhante ao estado de guerra. No entanto, o estado de natureza ainda não é verdadeiramente 0 estado de guerra, porque esses interesses privados em detrimento do bem comum ainda não são tão excessivos e predominantes na vida dos indivíduos.

No estado de natureza, geralmente, os indivíduos convivem em perfeita harmonia e em plena liberdade, embora não tenham leis civis que regulem os limites da ação individual. Todavia, isso só é possível devido ao critério da lei racional imanente à natureza. 0 homem é um ser capacitado a viver segundo a racionalidade em sua plenitude no processo de construção da organização social, independente de códigos civis e da presença de poderes que limitem as suas liberdades e posses. Assim diz Locke: "Um estado de perfeita liberdade para ordenar-Ihes as ações e regular-Ihes as posses e as pessoas conforme considerarem conveniente, dentro dos limites da lei da natureza, sem pedir permissão ou depender da vontade de qualquer outro homem" ${ }^{57}$.

Mesmo que o estado de natureza seja um estado de plena liberdade isto não implica um comportamento licencioso, indisciplinado, desregrado, sem um princípio que permita distinguir uma ação justa de uma ação injusta. Entretanto, o princípio da liberdade se identifica com o caráter de igualdade de cada indivíduo. Todos têm os mesmos direitos individuais ao exercer a faculdade de apropriar-se das riquezas naturais existentes em comum no universo como também o mesmo direito de estabelecer a conservação de sua própria vida. Isto porque a liberdade e a igualdade são princípios da natureza humana que fundamentam a existência do homem no estado de natureza e convergem em um princípio único e universal: a lei da razão. Essa lei é a causa primeira que coordena a vida dos homens. A liberdade

\footnotetext{
${ }^{56}$ Id., Segundo Tratado sobre o Governo, 45.

57 Ibid. 35.
} 
e a igualdade são qualidades determinantes para uma convivência pacífica entre os homens dotados de uma idêntica racionalidade, que Ihes possibilitam conhecer a lei natural e viver segundo esta lei. A liberdade do indivíduo é sempre uma liberdade condicionada pela liberdade do outro. A liberdade do homem, no estado de natureza, é condicionada pela lei natural, enquanto na sociedade política, essa liberdade está condicionada pelas leis estabelecidas pelo consenso $0^{58}$. 0 direito à liberdade é a condição de possibilidade para que o homem possa ser dotado de direitos inalienáveis em vista de sua autoconservação.

“No estado de natureza, os homens são 'livres' para dispor de si e de sua propriedade, independentemente da vontade de um outro, e são todos iguais. Liberdade e igualdade são características fundamentais do estado de natureza. Os homens podem ser muito diferentes entre si no que diz respeito a suas habilidades corporais e espirituais, mas todos têm o 'mesmo direito' de empregar essas habilidades para o uso da natureza" ${ }^{59}$.

A existência humana, nesse estágio da história, caracteriza-se por uma convivência de paz cujo fundamento é a obrigação do amor mútuo. 0 direito à própria liberdade traz em si o dever recíproco de respeito à liberdade do outro. Alguns homens, porém, fogem da orientação da lei da natureza e cometem infração aos direitos dos outros. "E neste caso, e pelo mesmo motivo, todos têm o direito de castigar o ofensor, tornando-se executores da lei da natureza"60. 0 ato de transgressão à lei da natureza merece ser punido.

Aqueles que vivem conforme a razão da lei da natureza são os árbitros porque têm o direito de punir os infratores uma vez que esses estão agindo contra a paz e a segurança estabelecidas pela lei da natureza. Quem não obedece à lei da natureza está em "estado de guerra" contra a humanidade. Apesar de todos os homens serem iguais e livres, alguns perdem parcialmente ou absolutamente a liberdade à medida que se tornam transgressores da lei. Aqueles que com isso sofreram dano tornam-se, conseqüentemente, superiores, enquanto detêm o direito de dispor da liberdade do outro a fim de aplicar penas proporcionais ao crime. 0 delito consiste no "violar a lei da natureza" e no "desviar da reta norma da razão". Certamente, há uma solidariedade dos que vivem retamente com aquele que se sentiu ofendido. A penalidade aplicada ao agressor tem uma dupla finalidade: punir 0 delito e prevenir análogos delitos. A punição requer reparação dos danos causados pelo ofensor ${ }^{61}$.

\footnotetext{
${ }^{58}$ Locke com a concepção de "liberdade condicionada" se opõe a Robert Filmer que concebia liberdade como "a faculdade que levaria cada um a seguir suas próprias inclinações, viver segundo a sua própria vontade, sem submeter-se à sujeição de nenhuma lei".

59 OLIVEIRA, M. A., Ética e Sociabilidade, Loyola, São Paulo, 1993, 119.

${ }^{60}$ LOCKE, J ., Segundo Tratado sobre o Governo, 37.

61 Ibid. 83.
} 
A proporcionalidade da pena em relação ao crime é um critério indispensável para impedir o domínio absoluto do árbitro sobre a vida do transgressor. Embora Locke afirme que não haja nenhuma punição que possa recompensar o crime de um assassinato, ele considera a pena de morte proporcional ao assassínio posto que quem comete tal crime declarou guerra a todo gênero humano. Nesse caso, o agressor perdeu absolutamente 0 direito à liberdade. A lei da natureza tem como objetivo básico proteger os inocentes e reprimir os transgressores.

A perda da liberdade ocorre não só com aqueles que são infratores, mas também com aqueles que se tornam escravos. A escravidão é a ausência absoluta da liberdade. 0 escravo é alguém que não possui nenhum domínio sobre a sua vida, pois a sua própria vontade está submetida ao poder absoluto e arbitrário do outro. A preservação da vida do escravo depende da vontade momentânea de seu senhor. A escravidão é o "estado de guerra continuado entre o conquistador legítimo e o cativo"62. Além disso, 0 escravo por não ser um homem livre não pode ser proprietário, ao contrário, ele é propriedade do seu senhor.

\section{0 direito à propriedade}

O termo "propriedade" é empregado por Locke seja em sentido amplo para referir-se à "vida, à liberdade e aos bens", seja em sentido restrito e exclusivo de bens materiais. "[...] A mútua conservação da vida, da liberdade e dos bens a que chamo de propriedade. [...] Fazendo cada um de melhor para preservar a si próprio, a sua liberdade e a sua propriedade $[\ldots]^{\prime \prime 63}$. A propriedade, a vida e a liberdade são direitos naturais inalienáveis dos indivíduos. Isto significa que o direito à autoconservação requer 0 direito à liberdade e o direito à propriedade como condições indispensáveis à concretização da existência dos indivíduos.

Segundo Locke, Deus deu aos homens a terra e todas as riquezas naturais e os fez dotados de razão para que eles fizessem bom uso de tais bens conforme as conveniências da vida. Contudo, só é possível usufruir dessas riquezas naturais pela apropriação individual. Apesar da doação de Deus ser comum a todos, 0 ato de usufruir desta riqueza natural é necessariamente individual. Este é o grande dilema do pensar lockiano quanto à propriedade: como ocorre a passagem da comunhão de possuidores universais para 0 nível de possuidores particulares? E como 0 ato de apropriação privada conserva o caráter de propriedade coletiva como dádiva de Deus?

Locke gradativamente vai argumentando que o direito de apropriação individual das riquezas naturais é condizente com a vontade de Deus e com a lei natural.

\footnotetext{
${ }^{62}$ LOCKE, J ., Segundo Tratado sobre o Governo, 43
}

63 I bid., p. 45. 
0 trabalho é a mediação pela qual alguém se apropria dos produtos naturais e da terra. 0 trabalho é um instrumento que permite a saída dos produtos naturais e da terra do estado comum a todos os homens ao estado privado. Essa passagem do estado comum das coisas naturais ao estado privado é perfeitamente legítima, uma vez que esse ato de privatização está em conformidade com a lei da natureza. 0 homem livre tem em sua própria pessoa a capacidade de dispor de bens, posto que cada um é uma propriedade inalienável à medida que é dono de sua própria vida. Portanto, tudo que provém de sua ação trabalhista é extensão de sua pessoa-propriedade. 0 resultado do trabalho pessoal é, então, propriedade individual de quem a adquiriu.

"Embora a terra e todas as criaturas inferiores sejam comuns a todos os homens, cada homem tem uma propriedade em sua própria pessoa; a esta ninguém tem qualquer direito senão ele mesmo. 0 trabalho de seu corpo e a obra de suas mãos, pode dizer-se que são propriamente dele" ${ }^{64}$.

O limite da apropriação por parte de cada um, pelo trabalho, é proporcional, originalmente, à sua capacidade de colher os frutos silvestres, caçar e cultivar uma determinada extensão de terra conforme as necessidades para o sustento da família, composta de cônjuges, filhos e escravos. A suposta limitação da propriedade pela mediação do trabalho é possível porque o cultivo da terra, a colheita de frutos silvestre e a caça aos animais eram feitos de maneira precária por falta de técnicas agrícolas avançadas, dificultando, assim, o acúmulo de grandes quantidades de terras e de alimentos. Não só o fator tecnológico punha limite ao processo de apropriação pelo mecanismo do trabalho, mas também a inexistência do dinheiro como instrumento que facilitasse a compra e a venda dos produtos naturais e da terra. "Onde não existe algo de duradouro e raro, de bastante valor que se conserve, os homens não estarão em condições de ampliar as próprias posses de terra mesmo que fosse muito rica, com plena liberdade de ocupá-la" ${ }^{\prime \prime}$. Nessa situação, anterior ao aparecimento do dinheiro, não havia interesses ambiciosos de acumular propriedades por parte dos homens. 0 trabalho como atividade físico-corpórea só possibilitava a apropriação limitada ao suprimento das necessidades de subsistência da família.

Um outro critério de limitação do processo de privatização da propriedade consiste no direito que todos possuem de se apropriar dos produtos naturais e da terra, contanto que deixem "bastante e tão bom para os outros". Pode-se pensar que esse critério tenha sido aplicado nas sociedades humanas nos primórdios do processo de povoamento de qualquer nação, já que o número de habitantes de uma nação em processo de povoamento é muito pequeno se comparado ao espaço geográfico. As grandes extensões de terras divididas entre os membros de uma pequena população possibili-

${ }^{64}$ Ibid.
${ }^{65}$ LOCKE, J., Segundo Tratado sobre o Governo, 53. 
tam a apropriação de terra de boa qualidade e de grande quantidade por todos os indivíduos. Esse limite chama-se limite da suficiência porque:

\begin{abstract}
“Veta a apropriação individual privilegiada que acarrete a disponibilidade qualitativa e quantitativa inferior de recursos para a apropriação por cada um dos outros indivíduos. Tal limite obriga o indivíduo a deixar como reserva comum produtos naturais ou terra suficientes para cada um dos outros indivíduos [...]"66.
\end{abstract}

Segundo o limite da suficiência, por mais ambicioso que seja o homem no que diz respeito à sua vontade de acúmulo de propriedade, sempre existirá oportunidade para que todos possam usufruir da terra e de suas riquezas pelo fato de que a população é muito pequena em relação à quantidade de terra à disposição de quem queira exercer 0 direito de apropriação.

0 terceiro momento do processo de apropriação dos produtos naturais ou da terra pode ser denominado de princípio de utilidade ou do não-desperdício. Esse princípio determina que os homens têm seus direitos limitados no ato de exploração das riquezas naturais, ao permitir que eles se apossem somente daquilo que é necessário ao suprimento das necessidades básicas de subsistência, não sendo admissível que a apropriação ultrapasse as conveniências do bem-estar da espécie humana. Evitar o desperdício ou a perda de produtos perecíveis é uma condição indispensável à reta razão. Por isso esse critério

"[...] que se pode chamar de limite da utilidade, obriga o indivíduo a restringir sua apropriação às utilidades, isto é, às necessidades de subsistência junto com as 'conveniências' da vida [...] [E]xclui-se da propriedade naturalmente legítima o luxo, pois ele não seria verdadeiramente uma utilidade, e sim uma forma de desperdício"67.

Nesse caso, somente é permitido que se acumulem alimentos não-perecíveis, sendo também possível uma troca do excedente perecível por produtos duráveis, que sejam aproveitáveis num tempo futuro. 0 excedente de mercadoria e o pequeno comércio se encontram no limite da utilidade, pois se proíbe somente 0 acúmulo de produtos perecíveis que seja causa de desperdício. A limitação da propriedade pelo critério do não-desperdício foi um passo que ultrapassou o simples limite da suficiência e abriu espaço para 0 ato de apropriação excessiva em conformidade com a lei da natureza. Aqui o comércio é entendido como um ato de troca de produtos perecíveis sem o uso do dinheiro. Contudo, pode-se pensar em desigualdade de propriedade entre os homens, uma vez que a proibição do desperdício não põe limite ao acúmulo de bens não-perecíveis. Usar a habilidade para acumular, sem permitir a futilidade e a deterioração, é um direito peculiar pertencente a todos os indivíduos. 0 princípio do não-desperdício

\footnotetext{
${ }^{66}$ J ORGE FILHO, E. J., Moral e História em Locke, Loyola, São Paulo, 1992, 80.

67 Ibid.
} 
ainda é uma tentativa de deixar reservas de terras e produtos naturais sujeitos à apropriação por partes de todos os homens, embora esse limite não evite as desigualdades quanto à qualidade e à quantidade da propriedade.

A apropriação pelo trabalho, o limite da suficiência e o limite da utilidade são critérios provenientes da lei da natureza que põem limites ao direito de propriedade. Segundo esses critérios, a apropriação está sujeita a uma racionalidade estabelecida pela lei da natureza. Contudo, os homens através de um consenso atribuíram ao ouro, à prata e aos diamantes um valor maior do que aquele que corresponde ao seu uso real em troca de coisas úteis à vida. Assim foi introduzido o dinheiro. 0 valor do uso do dinheiro foi estabelecido mediante um acordo tácito entre os homens, cuja medida de referência de valor de troca é o trabalho que se emprega na aquisição de qualquer gênero de propriedade.

\begin{abstract}
“Mediante um consenso tácito e voluntário, encontraram a maneira pela qual um homem pode chegar a possuir mais terra do que tem necessidade de usar, recebendo em troca de seu excedente uma quantidade de ouro e de prata que se pudesse armazenar sem causar nenhum tipo de prejuízo a ninguém $[. . .]^{\prime \prime 68}$.
\end{abstract}

Com o advento do dinheiro, surgiram maiores possibilidades de produção e de acúmulo uma vez que este passou a ser o denominador comum que permitiu aos homens a realização das transações comerciais. 0 valor convencional do dinheiro como um instrumento universal de troca viabilizou de modo explícito o desenvolvimento do comércio e implicitamente a desigualdade de propriedade. A apropriação ilimitada torna-se uma ação racional e justa porque o dinheiro é um mecanismo facilitador do comércio e da aquisição de propriedade, sem impor restrições aos indivíduos e está em concordância com a lei da natureza, visto que tal invenção ocorre a partir de um consenso estabelecido pelos indivíduos quanto ao valor de uso.

Se todos possuem as mesmas oportunidades de apropriar-se ilimitadamente dos recursos naturais, como surgem as diferenças econômicas? Ora, todos os homens são portadores de igual capacidade racional, contudo, uns foram diligentes ao empregá-la para ampliar as suas propriedades, tornando-se senhores; outros, ao contrário, foram negligentes, transformando-se em servos. "A essência da conduta racional é, portanto, a apropriação privada da terra e dos recursos materiais que produz e o investimento das próprias energias em melhorá-la para as conveniências da vida [...]"69. Acumular é, então, uma atitude sensata e justa visto que é um exercício de

${ }^{68}$ LOCKE, J ., Segundo Tratado sobre o Governo, 53.

69 MACPHERSON, C. B., A Teoria Política do Individualismo possessivo de Hobbes até Locke, tradução de Nelson Dantas, Paz e Terra, Rio de J aneiro, 1979, 245. 
exploração da racionalidade latente do homem que se tornou patente com 0 uso do dinheiro ${ }^{70}$.

\section{Defesa dos Direitos Humanos}

0 Renascimento, a Reforma Protestante e 0 Racionalismo ${ }^{71}$ são manifestações culturais que historicamente deram grande importância à categoria de indivíduo. 0 Renascimento, com seu caráter antropocêntrico, exalta a dignidade do homem e a sua vida intramundana em oposição ao dualismo antropológico medieval. A Reforma Protestante, sobretudo, o Calvinismo, com sua doutrina de emancipação da consciência do indivíduo, propõe uma ascese intramundana que orienta toda a vida do indivíduo em direção a Deus sem mediação da hierarquia eclesiástica. O Racionalismo, a partir do método empírico-analítico das ciências, propõe ao homem uma vida orientada unicamente pela Razão em oposição ao autoritarismo exercido pelo Estado e pela Igreja sobre as consciências dos indivíduos.

O espírito científico do homem moderno se manifesta como refutação da cosmovisão mitológica do homem medieval. A confiança na razão humana se apresenta de modo otimista como a capacidade do homem de exercer o seu livre domínio sobre a natureza e sobre a vida social. A liberdade do indivíduo é a maior expressão da dignidade do homem contra todo poder autoritário. 0 racionalismo e 0 naturalismo constituem as características fundamentais da cosmovisão do homem moderno. A confiança na razão como único guia seguro da vida privada e da vida pública e o desenvolvimento das ciências naturais criaram a possibilidade da elaboração de um pensamento político que leva em consideração a liberdade e a razão como condições indispensáveis de uma organização sócio-política coerente com a natureza do próprio homem. Portanto, o império da razão implicou 0 reconhecimento da autonomia do indivíduo.

Neste contexto histórico-cultural, Locke elaborou a sua teoria política tendo como pressuposto antropológico a compreensão de homem, como livre e racional. A liberdade e a razão são os constitutivos da condição humana: todos os homens são iguais. 0 princípio de igualdade como referência à dignidade humana é um dado significativo à medida que impede a

\footnotetext{
70 Locke ao falar do aumento da produção como uma atitude racional se aproxima da concepção de Weber, quando este último em sua famosa obra "A Ética Protestante e o Espírito do Capitalismo" (1904), analisa a relação entre a mentalidade religiosa e o desenvolvimento econômico da sociedade burguesa. A riqueza e a pobreza são, respectivamente, conseqüências da diligência e da negligência no uso da racionalidade no processo do trabalho.

${ }^{71}$ Cf. MATTEUCCI, N., "Liberalismo", in Dizionario di Politica, UTET, Torino, 1983, 592-610. A referência aqui mencionada às etapas históricas da exaltação do conceito de "indivíduo" se encontra precisamente na página 600.
} 
legitimação do domínio absoluto do homem sobre o homem. E como ser livre e racional, todo indivíduo é detentor de direitos inalienáveis: a vida, a liberdade e a propriedade. A propriedade é um direito inalienável, posto que é a condição necessária à preservação da vida e da liberdade do indivíduo. Por isso, é indispensável um governo que esteja atento à justiça social a fim de que a cidadania implique reconhecimento dos direitos e dos deveres de todos os cidadãos que constituem o Estado-Nação.

Locke, pensador jusnaturalista, defende a existência da lei natural como ponto de partida para a compreensão da retidão das leis civis. 0 homem é dotado de faculdades cognitivas que Ihe possibilitam conhecer os direitos e os deveres originários da lei natural e das leis civis. Pensar o homem como indivíduo dotado de direitos é relevante porque evita a massificação ou a coisificação da pessoa pelas estruturas sócio-políticas. 0 primado do indivíduo sobre a instituição é indispensável visto que as instituições são mediações de proteção aos Direitos Humanos.

Locke fala do primado da lei natural e da lei eterna de Deus nos confrontos com as leis positivas do Estado. As leis civis só são portadoras de credibilidade quando estão em concordância com a racionalidade do homem e com a vontade de Deus. 0 indivíduo como ser dotado de direitos tem a liberdade de escolha não só da forma de governo, mas também da religião. A liberdade religiosa é um direito de todo cidadão. 0 governo não tem 0 direito de impor ao súdito nenhum tipo de credo religioso. 0 Estado tem o seu âmbito de ação limitado às questões públicas de interesse dos indivíduos; no entanto, não pode interferir, arbitrariamente, na vida familiar, econômica e religiosa, já que essas dimensões constituem a vida privada dos indivíduos que implica o máximo de liberdade de ação.

A partir do século XVIII, a Europa e a América foram influenciadas pelo pensamento político de Locke. 0 pensamento político-religioso de Locke contido em sua Carta sobre a Tolerância (1689) e em seu Segundo Tratado sobre o Governo (1690) possibilitou o reconhecimento do homem como um ser portador de direitos. Isto se encontra de modo explícito na "Declaração dos Direitos do Homem e do Cidadão72" (Déclaration des droits de l'homme

\footnotetext{
72 Cf. MATTEuCCI, N. \& MENGOZZI, P., "Diritti dell'uomo”, in Dizionario di Politica, UTET, Torino, 1983, pp. 326-334.1 J usnaturalismo é a corrente filosófica ou doutrina que sustenta a existência de uma lei natural, no sentido de que as suas normas precedem logicamente às leis ou aos direitos positivos que emanam de uma autoridade política ou religiosa. A história do conceito do direito natural nos remete à filosofia clássica, e quando se fala de «doutrina» ou de «escola» do direito natural, com o termo «jusnaturalismo» faz-se referência ao desenvolvimento e à difusão que a antiga corrente do direito natural teve durante a Idade Moderna, no período que ocorre entre o início do século XVI e o final do século XVII. Sob a denominação de «escola do direito natural» encontram-se autores e correntes muito diferentes e até opostas, representadas pelos grandes filósofos políticos Hobbes, Leibniz, Locke, Rousseau, Kant e por juristas filósofos como Pufendorf, Thomasius e Wolf.
} 
et $d u$ citoyen) em 1789 que foi introduzida na Constituição francesa de 1791. Proclamavam-se, então, a "liberdade" e a "igualdade" como princípios inerentes aos direitos naturais de todos os homens, que servirão como pressupostos da legitimidade de qualquer sociedade política. Todavia, dois fatos significativos antecederam à "Declaração dos Direitos do Homem e do Cidadão": a Revolução Gloriosa de 1689 (Bill of rights) e a Independência das treze colônias americanas do domínio da Inglaterra em 1776 (Bills of rights). Há uma diferença entre esses dois fatos históricos quanto aos Direitos Humanos: o primeiro significou especificamente a reivindicação dos direitos dos cidadãos ingleses contra o poder absolutista do rei, enquanto o segundo reconhecia a universalidade dos direitos de todos os homens.

Durante a Revolução Francesa houve duas Declarações importantíssimas referentes aos Direitos Humanos: 1793 e 1795. Na Declaração de 1793 os direitos humanos apresentavam um caráter mais social, já que ela, embora valorizasse a liberdade e a igualdade dos indivíduos, dava maior ênfase à vivência da "fraternidade". A Declaração de 1795 falava não somente de "direitos" mas também de "deveres" dos cidadãos. A Constituição Americana de 1781, que foi elaborada por James Madison e George Washington, foi a primeira a incluir os direitos humanos no próprio texto da Carta Magna de um país.

Após as duas trágicas guerras mundiais, houve uma preocupação internacional com a garantia institucional em defender os direitos dos indivíduos, cuja manifestação maior foi a "Declaração Universal dos Direitos do Homem" pela ONU em 1948.

Os Direitos Humanos podem ser classificados em três categorias: civis, políticos e sociais. Os direitos civis se referem à liberdade pessoal, à liberdade de imprensa, de religião, de associação e liberdade econômica. Os direitos políticos correspondem à liberdade de associação partidária e aos direitos eleitorais. Os direitos sociais compreendem questões a respeito da saúde, do trabalho, da educação, de moradia etc. A tomada de consciência dos direitos naturais é o primeiro passo para que cada um defenda individual e coletivamente a concretização dos Direitos humanos em prol da construção ética da cidadania.

\section{Conclusão}

Queremos concluir a reflexão antropológico-ética que fizemos sobre a doutrina lockiana dos direitos naturais como fundamentação da defesa dos direitos humanos, dando ênfase às idéias fundamentais de nossa pesquisa, à luz das seguintes proposições: 
01. Na doutrina jusnaturalista moderna, a sociabilidade é um artifício indispensável aos indivíduos para superar sua tendência natural a viver isolados. A vida social nasce a partir de um contrato entre os diversos indivíduos a fim de tornar possível a convivência social.

02. A doutrina lockiana do direito natural afirma que a lei natural possui um caráter ético-político já que a lei da natureza subsiste como uma norma eterna para todos os homens.

03. No estado de natureza, segundo Locke, os homens gozam de direitos regulados pela lei da natureza. Os direitos naturais prioritários são: a autoconservação, a liberdade e a propriedade. A autoconservação como direito fundamental do homem não pode ser entendido em sentido individualista, visto que ele sustenta a responsabilidade do indivíduo pela conservação da vida do outro. Deus como autor da lei natural aspira à conservação não só do indivíduo particular, mas também de toda a humanidade. A liberdade e a propriedade estão a serviço da autoconservação, por isso 0 indivíduo que viola esse direito pode vir a perder a própria vida já que ao transgredi-lo está se declarando inimigo da comunidade humana. Do mesmo modo, o Estado poderá ser destituído, quando o transgride, não respeitando às leis estabelecidas pelo consenso, uma vez que a sua finalidade é proteger os direitos dos indivíduos existentes no estado de natureza.

04. 0 indivíduo como ser dotado de direito tem a liberdade de escolha não só da forma de governo, mas também da religião. A liberdade religiosa é um direito de todo cidadão. 0 governo não tem o direito de impor ao súdito nenhum tipo de credo religioso.

05. 0 voto universal e consciente, o plebiscito, o referendum, o impeachment são instrumentos úteis como controle da ação consensual do governo em relação à sociedade civil.

06. O Estado é uma mediação reguladora dos interesses competitivos de todos os cidadãos que formam uma determinada sociedade.

07. A doutrina do direito natural e a teoria do contrato social fizeram de Locke um clássico da cultura ocidental, com sua proposta política jusnaturalista, coerente com os valores culturais do homem contemporâneo.

08. Enfim, a consciência de que o ser humano é dotado de Direitos Naturais possibilita a fundamentação da defesa dos Direitos Humanos inalienáveis: a vida, a liberdade e a propriedade. Por isso, é necessário que as organizações, governamentais ou não, estejam sempre vinculadas aos princípios da igualdade e da solidariedade como norteadores da promoção humana. 


\section{Bibliografia}

AGOSTINHO, O Livre Arbítrio, tradução de Nair de Assis Oliveira, Paulus, São Paulo, 1995.

, Confissões, tradução de J. Oliveira Santos e A. Ambrósio de Pina, Nova Cultural, São Paulo, 2004.

, Enarraciones sobre los Salmos 144, 13, in Obras Completas de San Agustín, XXII, Edición Bilingüe, BAC, Madrid, 1967.

Roma, 1997.

, La Città di Dio XII,7,12, traduzione di Domenico Gentili, Città Nuova,

ARISTÓTELES, Ética a Nicômaco, tradução de Leonel Vallandro e Gerd Bornheim, Nova Cultural, São Paulo,1987. , Política, Nova Cultural, São Paulo, 2004.

, Retorica, in Opere, vol. X, Laterza, Bari, 1973

BOBBIO, N., Locke e I/ Diritto Naturale, Giappichelli, Torino, 1963.

BOBBIO, N., MATTEUCCI, N. \& G. PASQUINo, Dizionario di Politica, UTET, Torino, 1983.

CHEVALIER, J.-J., As Grandes Obras Políticas: de Machiavel a nossos dias. Tradução de Lydia Christina, Agir, Rio de Janeiro, 1980.

DUNN, J., II Pensiero Político di John Locke, traduzione di Biancamaria Fontana e Pasquale Pasquino, II Mulino, Bologna, 1992.

EPICURO, Antologia de Textos de Epicuro, Tradução de Agostinho Sicro, Abril Cultural, São Paulo, 1973.

$\overline{2} 0 \overline{0} \overline{1}$.

, Lettera a Meneceo, traduzione di Nicoletta Russello, Fabri, Milano,

EUCHNER, W., La Filosofia Politica di Locke, Traduzione di Katja Tenembaum, Laterza, Roma-Bari, 1995.

GRUPPI, L., Tudo começou com Maquiavel. Tradução de Dario Canali, L \& PM, São Paulo, 1982.

HELD, D., Modelli di Democrazia, traduzione di Umberto Livini e Luca Verzichelli, il Mulino, Bologna, 1997.

HOBBES, T., Leviatã (matéria, forma e poder eclesiástico e civil). Tradução Alex Marins, Martin Claret, São Paulo, 2002.

JORGE FILHO, E. J., Moral e História em Locke, Loyola, São Paulo, 1992.

LOCKE, J., Second Treatise of Government, Hackett Publishing Company, USA, 1980. , Segundo Tratado sobre o Governo, tradução de E. Jacy Monteiro, Abril Cultural, São Paulo, 1978.

- Carta acerca da Tolerância, tradução de Anoar Aiex e E. Jacy Monteiro, Ábril Cultural, São Paulo, 1978. 
, Ensaio sobre o Entendimento Humano, tradução de Anoar Aiex e E. Jacy Monteiro, Abril Cultural, São Paulo, 1978. Bari, $19 \overline{9} \overline{6}$.

Saggi sulla Legge naturale, traduzione di Marta Cristiani, Laterza, Roma, Pensieri sull'Educazione, La Nuova Italia, Firenze, 1989.

MACPHERSON, C. B., A Teoria Política do Individualismo possessivo de Hobbes até Locke, tradução de Nelson Dantas, Paz e Terra, Rio de Janeiro, 1979.

OLIVEIRA, M. A., Ética e Sociabilidade, Loyola, São Paulo, 1993.

PLATÃO, A República IX, tradução de Enrico Corvisieri, Nova Cultural, São PauI0, 2004.

TOMAS DE AQUINO, Suma de Teologia, 5 vol., edición dirigida por los Regentes de Estúdios de las Províncias Dominicanas en España, BAC, Madrid, 1997.

THOMAE AQUINATIS, De regimine principum, Joseph Mathis curante, Taurini, 1924.

VV. AA., Os Filósofos através dos Textos (de Platão a Sartre), Paulus, São Paulo, 2003.

VIANO, C. A., II Pensiero Politico di Locke, Laterza, Roma-Bari, 1997.

WEBER, M., A Ética Protestante e o Espírito do Capitalismo, tradução de M. Irene de Q.F. Szmrecsány e Tomás J.M.K. Szmrecsány, Pioneira, São Paulo, 1987.

Endereço do Autor:

Rua Antônio Martins, 344 / 202

62700-000 Canindé - CE 